\title{
1st Circular
}

\section{Bioavailability '93}

\section{Nutritional, Chemical and Food Processing Implications of Nutrient Availability}

\section{Ettlingen, May 9-12, 1993}

Co-sponsored by: Federation of European Chemical Societies - Working Party on Food Chemistry, Federation of European Nutrition Societies

\section{Location}

The Conference will be held in the historic Castle of Ettlingen, $3 \mathrm{~km}$ from Karlsruhe, Federal Republic of Germany

\section{Scientific committee}

J. F. Diehl (Chairman) (Karlsruhe), W. Baltes (Berlin), R. Bitsch (Paderborn), P. B. Czedik-Eysenberg (Wien), H. Deelstra (Antwerpen), H. F. Erbersdobler (Kiel), L. Hallberg (Göteborg), M. Kirchgeßner (Weihenstephan), C. Mercier (Paris), U. Schlemmer (Karlsruhe), W.E.L. SpieB (Karlsruhe), D. A. T. Southgate (Norwich), A. G. J. Voragen (Wageningen)

\section{Organisation committee}

J.F. Diehl (Karlsruhe), K.-D. Jany (Karlsruhe), U. Schlemmer (Karlsruhe), T. Storck (Karlsruhe), J. Wever (Karlsruhe)

\section{Aims of the symposium}

This symposium will be of interest to scientists from the fields of nutrition, biomedical science, food chemistry and food technology. It will document developments which have taken place in this area over the last four years and will be a follow-up conference to „Bioavailability '88, Chemical and Biological Aspects of Nutrient Availability“ held in 1988 in Norwich, UK.

\section{Main topics}

- Bioavailability of micro and macro nutrients from food

- Mechanisms of nutrient absorption and interferences upon them by food components or their degradation products

- Interaction of food components with digestive enzymes and nutrients during the gastrointestinal passage

- Measurement of nutrient absorption and status

- Chemical reactions in food during processing and storage, and their effect on bioavailability of nutrients

- Effects of technical and biotechnical processes on bioavailability of nutrients

- Bioavailability of nutrients with age and malfunction of intestine

Key dates

2nd circular: July 1, 1992

Submission of abstracts: October 1, 1992

Conference language

English

Contact

Dr. U. Schlemmer

Bundesforschungsanstalt für Ernährung, (Federal Research Centre for Nutrition) Engesserstrasse 20, W-7500 Karlsruhe 1, Federal Republic of Germany

Phone: (49)(7247) 823600 or 823603

Fax: (49)(7247) 22820 